\title{
Summary of Operations and Performance of the Utica Aquifer and North Lake Basin Wetlands Restoration Project in December 2006-November 2007
}

Environmental Science Division 


\begin{abstract}
About Argonne National Laboratory
Argonne is a U.S. Department of Energy laboratory managed by UChicago Argonne, LLC under contract DE-AC02-06CH11357. The Laboratory's main facility is outside Chicago, at 9700 South Cass Avenue, Argonne, Illinois 60439. For information about Argonne, see www.anl.gov.
\end{abstract}

\title{
Availability of This Report
}

This report is available, at no cost, at http://www.osti.gov/bridge. It is also available on paper to the U.S. Department of Energy and its contractors, for a processing fee, from:

U.S. Department of Energy

Office of Scientific and Technical Information

P.O. Box 62

Oak Ridge, TN 37831-0062

phone (865) 576-8401

fax (865) 576-5728

reports@adonis.osti.gov

\section{Disclaimer}

This report was prepared as an account of work sponsored by an agency of the United States Government. Reference herein to any specific commercial product, process, or service by trade name, trademark, manufacturer, or otherwise, does not necessarily constitute or imply its endorsement, recommendation, or favoring by the United States Government or any agency thereof. The views and opinions of document authors expressed herein do not necessarily state or reflect those of the United States Government or any agency thereof, Argonne National Laboratory, or UChicago Argonne, LLC. 


\section{Summary of Operations and Performance of the Utica Aquifer and North Lake Basin Wetlands Restoration Project in December 2006-November 2007}

by

Applied Geosciences and Environmental Management Section

Environmental Science Division, Argonne National Laboratory

February 2008

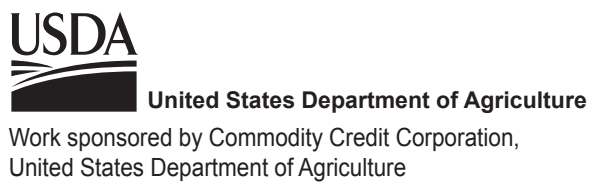




\section{Contents}

Notation.

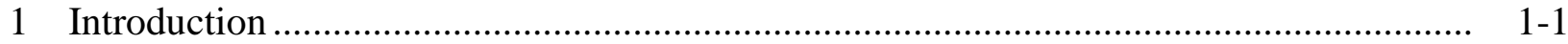

2 Overview of the Aquifer Restoration Facilities at Utica........................................ 2-1

2.1 Wells GWEX1-GWEX3 and the Spray Irrigation Treatment Units ..................... 2-1

2.2 Well GWEX4 and the Conventional Air Stripper................................................ 2-2

2.3 Monitoring Well Network ......................................................................... 2-2

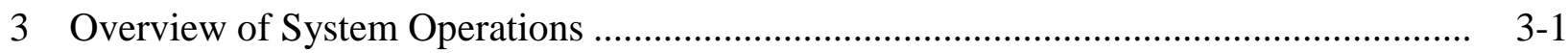

3.1 Operation of Wells GWEX1-GWEX3 and the Spray Irrigation Treatment Units.... 3-1

3.2 Operation of Well GWEX4 and the Conventional Air Stripper ........................... 3-2

4 Groundwater Production Results .........................................................................

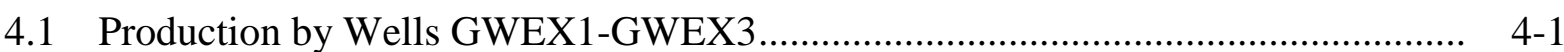

4.2 Production by Well GWEX4

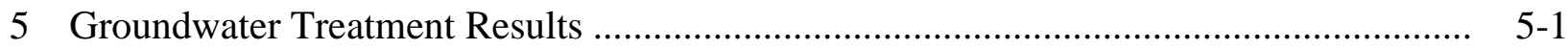

5.1 Results for Wells GWEX1-GWEX3, with Treatment by Spray Irrigation.............. 5-2

5.2 Results for Well GWEX4, with Treatment by Air Stripping .................................. $5-5$

5.3 Estimated Removal of Carbon Tetrachloride from the Utica Aquifer .................... 5-6

5.4 Sampling of Monitoring Wells and Apparent Carbon Tetrachloride Concentration Trends in the Utica Groundwater .............................................................................. $5-6$

5.5 Evaluation of Groundwater Inorganic Geochemistry …................................. $5-9$

6 Operation, Maintenance, and System Modifications ............................................. $6-1$

6.1 Wells GWEX1-GWEX3 and the Spray Irrigation Treatment Units ..................... 6-1

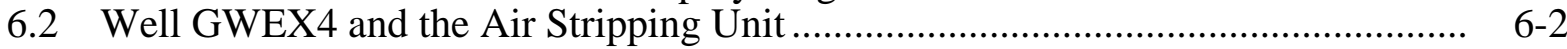

6.3 Operating and Maintenance Costs in December 2006-November 2007 .................. 6-2

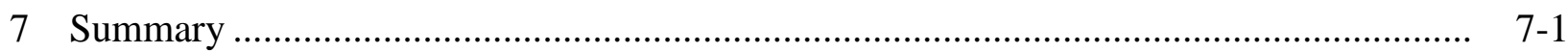

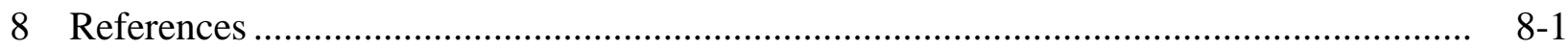




\section{Figures}

2.1 Locations of the restoration facilities, contaminant plume, and permanent monitoring wells at Utica

2.2 Spray irrigation unit in operation at Utica

5.1 Carbon tetrachloride concentrations at monitoring wells MW1-MW4, September 2005 to October 2007

5.2 Carbon tetrachloride concentrations at extraction well GWEX1, November 2004 to November 2007.

5.3 Carbon tetrachloride concentrations at extraction well GWEX2, November 2004 to November 2007

5.4 Carbon tetrachloride concentrations at extraction well GWEX3, November 2004 to November 2007.

5.5 Carbon tetrachloride concentrations at extraction well GWEX4, November 2004 to November 2007.

\section{Tables}

2.1 Summary of construction details for GWEX wells at Utica.....

4.1 GWEX operation and groundwater production data in December 2006-

November 2007

4.2 Comparison of actual well production rates and target rates

5.1 Analytical results for carbon tetrachloride in untreated groundwater samples and treated effluent samples in December 2006-November 2007.

5.2 Values for $\mathrm{pH}$ in untreated groundwater samples and treated effluent samples in December 2006-November 2007

5.3 Estimation of carbon tetrachloride removed from the Utica aquifer in December 2006-November 2007

5.4 Well construction data and analytical results for carbon tetrachloride in groundwater samples from the permanant monitoring wells 
Utica Annual Review, December 2006-November 2007

Version 00, 02/11/08

5.5 Comparison of inorganic geochemical results for untreated groundwater samples and treated effluent samples

6.1 Summary of operating and maintenance costs for the Utica restoration project ......... 6-3

7.1 Summary of performance of the groundwater restoration systems at Utica ................ 7-3 


\section{Notation}

$\begin{array}{ll}\text { BGL } & \text { below ground level } \\ \mathrm{CCC} & \text { Commodity Credit Corporation } \\ { }^{\circ} \mathrm{F} & \text { degree(s) Fahrenheit } \\ \mathrm{ft} & \text { foot (feet) } \\ \text { gal } & \text { gallon(s) } \\ \text { gpm } & \text { gallon(s) per minute } \\ \text { GWEX } & \text { groundwater extraction } \\ \text { hr } & \text { hour(s) } \\ \text { in. } & \text { inch(es) } \\ \text { kg } & \text { kilogram(s) } \\ \text { L } & \text { liter(s) } \\ \mu \mathrm{g} / \mathrm{L} & \text { microgram(s) per liter } \\ \text { mph } & \text { mile(s) per hour } \\ \text { mg/L } & \text { milligram(s) per liter } \\ \text { MW } & \text { monitoring well } \\ \text { NDEQ } & \text { Nebraska Department of Environmental Quality } \\ \text { NGPC } & \text { Nebraska Game and Parks Commission } \\ \text { NPDES } & \text { National Pollutant Discharge Elimination System } \\ \text { USDA } & \text { U.S. Department of Agriculture } \\ \text { VOC } & \text { volatile organic compound } \\ & \end{array}$




\section{Summary of Operations and Performance of the Utica Aquifer and North Lake Basin Wetlands Restoration Project in December 2006-November 2007}

\section{Introduction}

This document summarizes the performance of the groundwater restoration systems installed by the Commodity Credit Corporation of the U.S. Department of Agriculture (CCC/USDA) at the former CCC/USDA grain storage facility in Utica, Nebraska, during the third year of system operation, from December 1, 2006, until November 30, 2007.

In the project at Utica, the CCC/USDA is cooperating with multiple state and federal agencies to remove carbon tetrachloride contamination from a shallow aquifer underlying the town and to provide supplemental treated groundwater for use in the restoration of a nearby wetlands area. Argonne National Laboratory has assisted the CCC/USDA by providing technical oversight for the aquifer restoration effort and facilities during this review period.

This document presents overviews of the aquifer restoration facilities (Section 2) and system operations (Section 3), then describes groundwater production results (Section 4); groundwater treatment results (Section 5); and associated groundwater monitoring, system modifications, and costs during the review period (Section 6). Section 7 summarizes the present year of operation and provides some comparisons with system performance in previous years.

The performance of the groundwater restoration systems at Utica in earlier years was summarized in greater detail previously (Argonne 2005, 2006). 


\section{Overview of the Aquifer Restoration Facilities at Utica}

The principal components of the groundwater restoration systems at Utica are shown in Figure 2.1. The facilities consist of two main operating units, as described below. The facilities include four groundwater extraction (GWEX) wells. Table 2.1 summarizes construction details for these wells.

\subsection{Wells GWEX1-GWEX3 and the Spray Irrigation Treatment Units}

Extraction wells GWEX1-GWEX3, located in the northern portion of the town, are used to extract contaminated groundwater from the upgradient portion of the contaminant plume. These wells are linked by a distribution system that selectively carries untreated groundwater to either of two discharge points in the northern and southern subbasins of the North Lake Basin Wildlife Management Area (Figure 2.1). At each discharge point, the water is treated to remove carbon tetrachloride by using a custom spray irrigation treatment unit (Figure 2.2). The three extraction wells are operated simultaneously to maintain a critical operating pressure at each treatment unit.

Wells GWEX1-GWEX3 are operated intermittently during the year, subject to local weather conditions and in consultation with the Nebraska Game and Parks Commission (NGPC). The NGPC owns most of the property occupied by the wetlands and has administrative and technical responsibility for management of the wildlife area.

TABLE 2.1 Summary of construction details for GWEX wells at Utica.

\begin{tabular}{ccccc}
\hline & \multicolumn{3}{c}{ Depth (ft BGL) } \\
\cline { 2 - 4 } Well & Depth & $\begin{array}{c}\text { Screen } \\
\text { Interval }\end{array}$ & $\begin{array}{c}\text { Gravel } \\
\text { Pack } \\
\text { Interval }\end{array}$ & $\begin{array}{c}\text { Casing } \\
\text { Diameter } \\
\text { (in.) }\end{array}$ \\
\hline GWEX1 & 132 & $106-126$ & $97-132$ & 8 \\
GWEX2 & 148 & $110-145$ & $106-148$ & 8 \\
GWEX3 & 146 & $105-140$ & $101-146$ & 8 \\
GWEX4 & 150 & $115-145$ & $110-150$ & 6 \\
\hline
\end{tabular}




\subsection{Well GWEX4 and the Conventional Air Stripper}

Extraction well GWEX4 is located near the downgradient toe of the carbon tetrachloride plume and is operated continuously as a containment well. Groundwater produced from GWEX4 is treated by using a conventional (shallow-tray) air stripping technique, and the effluent is discharged to the surface for reinfiltration into the shallow Utica aquifer.

\subsection{Monitoring Well Network}

A network of seven permanent monitoring points has been established at Utica (Figure 2.1). Wells SB48, SB71, and SB72 were constructed during the early phases of the investigations at Utica. These wells were intended primarily for the measurement of groundwater levels; they do not penetrate the more contaminated zones of the groundwater column identified in detailed vertical-profile sampling (Argonne 2000). To improve monitoring coverage, additional wells MW1-MW4 (Table 2.1) were installed at strategic locations along the plume migration pathway in August 2005. 


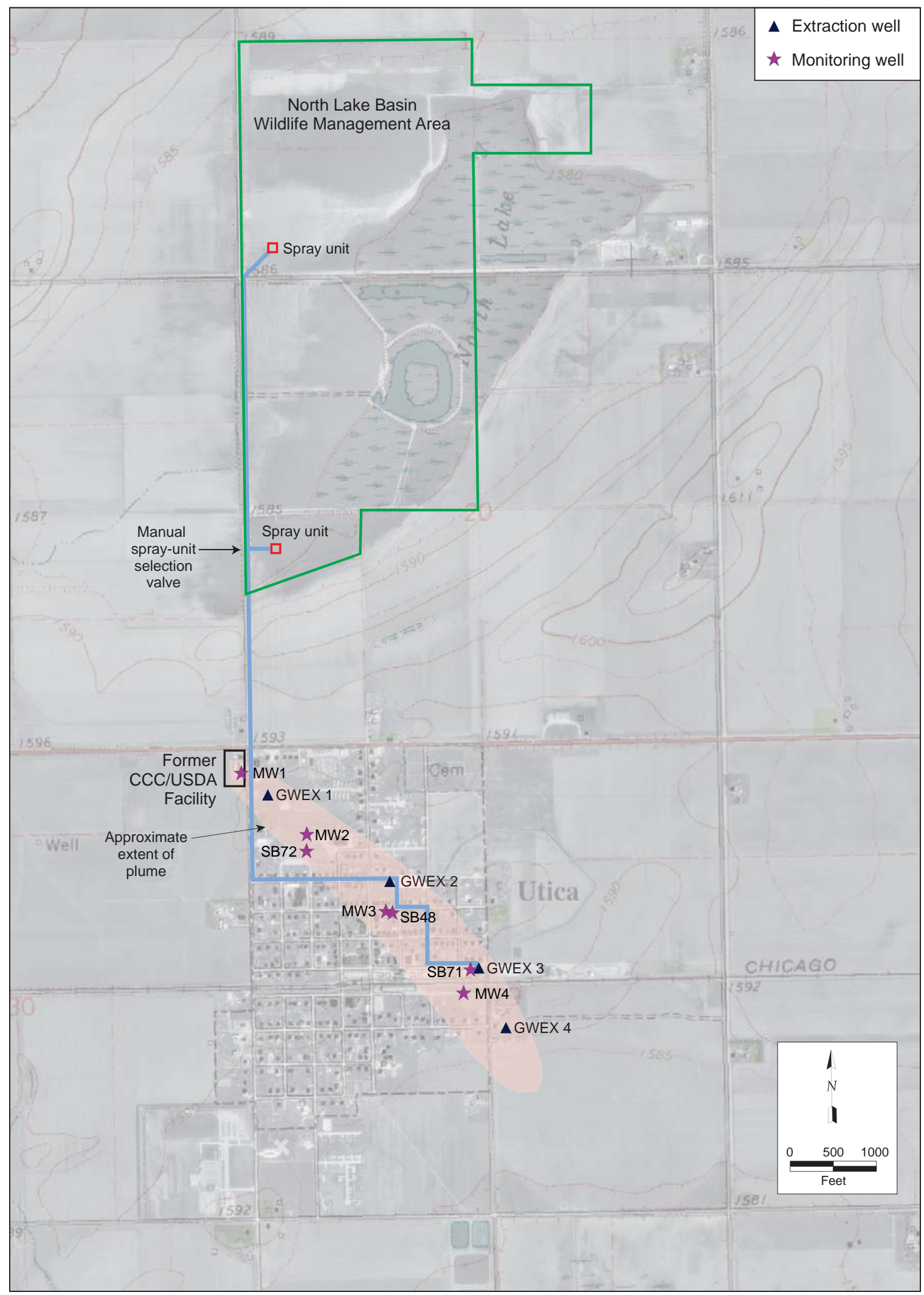

FIGURE 2.1 Locations of the restoration facilities, contaminant plume, and permanent monitoring wells at Utica. 


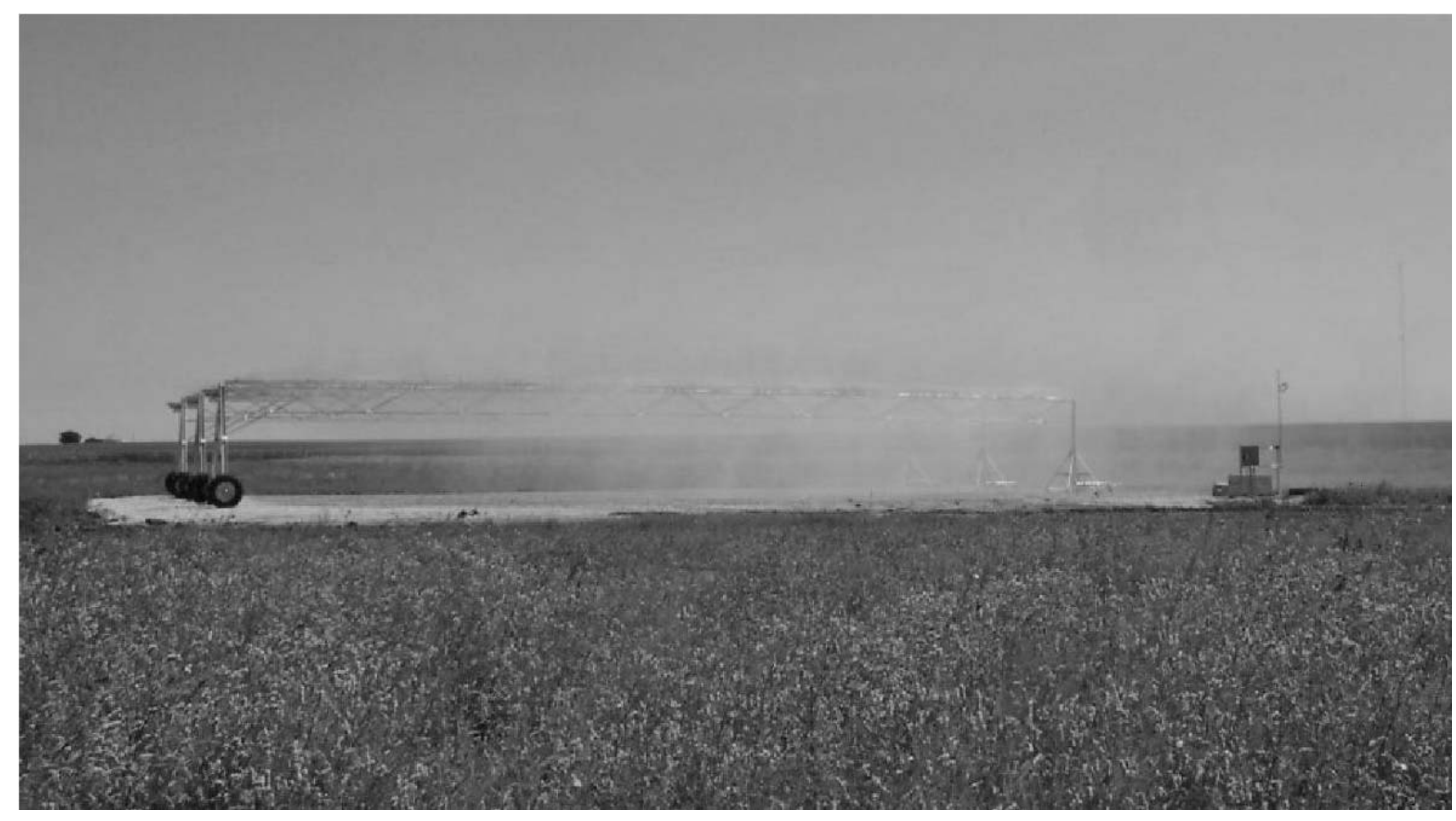

FIGURE 2.2 Spray irrigation unit in operation at Utica. 


\section{Overview of System Operations}

\subsection{Operation of Wells GWEX1-GWEX3 and the Spray Irrigation Treatment Units}

Wells GWEX1-GWEX3 and the spray irrigation treatment units were operated intermittently, under automated control, during 11 of the 12 months in the review period. The daily operation of the spray treatment units is governed primarily by weather conditions. To ensure effective removal of the carbon tetrachloride and to prevent excessive drift of the resulting spray discharge, a minimum air temperature of $40^{\circ} \mathrm{F}$ and sustained winds of less than $20 \mathrm{mph}$ are required for operation. The extraction wells and treatment units did not operate in February 2007 because of inclement weather conditions.

Treated groundwater from the spray irrigation systems was selectively routed to both the north and south subbasins during the review period. Treated groundwater was discharged exclusively to the north subbasin during the winter of 2006-2007 and during the spring and early summer of 2007.

In early March 2007, flow rates from GWEX1 were observed to be lower than normal during a routine attempt to restart GWEX1-GWEX3 following a period of cold weather. Water leakage was discovered from an air release valve along the pipeline linking GWEX1 to the central control building. The air release valve, housed in a manhole near the city of Utica maintenance facility (south of GWEX1; Figure 2.1), was temporarily bypassed and subsequently repaired, with no interruption of normal operations. Similarly, a damaged pipeline valve actuator (which facilitates remotely controlled operation and automatic drainage of the spray treatment irrigation spans) discovered in late March was bypassed to permit continued discharge of treated groundwater to the north subbasin. The actuator was replaced during the summer of 2007.

Unexpected shutdowns of GWEX1-GWEX3 and the spray treatment units occurred sporadically during May and June 2007. The cause of these incidents was traced to spurious signals from an electronic water level sensor installed in well GWEX2. After the sensor was reprogrammed in early July 2007, no further service interruptions of this type occurred.

In August 2007, a transformer failure in the electrical control panel at the north subbasin temporarily prevented the use of the spray irrigation unit at this location. With the approval of the NGPC, groundwater was therefore routed to the south subbasin spray treatment unit. The 
control panel was repaired in September 2007; however, discharge of treated groundwater to the south subbasin continued through the remainder of the review period.

\subsection{Operation of Well GWEX4 and the Conventional Air Stripper}

Well GWEX4 and the associated air stripper were operated during 11 of the 12 months in the review period.

Treated groundwater from well GWEX4 is discharged to an open ditch that serves as part of Utica's storm drainage system. The ditch borders a county road leading eastward from the town, as well as adjacent private farm properties. At the request of the Utica city council, GWEX4 and the air stripper were not operated for the month of May 2007, to permit anticipated maintenance of the drainage ditch by Seward County personnel. The expected maintenance did not take place, however, and GWEX4 and the air stripper were returned to service at the beginning of June.

Argonne received no reports of drainage problems or other problems associated with the discharge from GWEX4 during the review period. 


\section{Groundwater Production Results}

The volumes of groundwater extracted from the Utica aquifer, treated, and discharged during the current review period are summarized in Table 4.1. Performance during the three years of system operation to date is summarized in Section 7.

TABLE 4.1 GWEX operation and groundwater production data in December 2006-November 2007.

\begin{tabular}{|c|c|c|c|c|c|c|c|c|}
\hline \multirow[b]{3}{*}{ Month } & \multicolumn{4}{|c|}{ Wells GWEX1-GWEX3 } & \multirow{2}{*}{\multicolumn{2}{|c|}{$\begin{array}{c}\text { Volume Discharged to } \\
\text { Wetlands }^{c} \text { (gal) }\end{array}$}} & \multicolumn{2}{|c|}{ GWEX4 } \\
\hline & \multicolumn{3}{|c|}{ Groundwater Produceda } & \multirow{2}{*}{$\begin{array}{l}\text { Operating } \\
\text { Time }^{\text {b }} \\
\text { (hr) }\end{array}$} & & & \multirow{2}{*}{$\begin{array}{c}\text { Groundwater } \\
\text { Produced } \\
\text { (gal) }\end{array}$} & \multirow{2}{*}{$\begin{array}{c}\text { Operating } \\
\text { Time } \\
\text { (days) }\end{array}$} \\
\hline & GWEX1 & GWEX2 & GWEX3 & & North & South & & \\
\hline Dec 06 & 287,700 & $1,143,000$ & 716,800 & 95.4 & 2147500 & $-d$ & 2697174 & 31 \\
\hline Jan 07 & 54,200 & 215,100 & 134,900 & 18.0 & 404200 & - & 2708244 & 31 \\
\hline Feb 07 & - & - & - & - & - & - & 2506360 & 28 \\
\hline Mar 07 & 898,400 & $4,114,300$ & $2,580,000$ & 337.5 & 7592700 & - & 2785704 & 31 \\
\hline Apr 07 & 660,600 & $2,631,400$ & $1,649,200$ & 219.6 & 4941200 & - & 2744008 & 30 \\
\hline May 07 & $1,716,600$ & $6,827,500$ & $4,283,700$ & 570.1 & 12827800 & - & - & 0 \\
\hline Jun 07 & $1,267,700$ & $5,050,600$ & $3,165,400$ & 422.0 & 9483700 & - & 1931632 & 25 \\
\hline Jul 07 & $1,543,200$ & $6,145,600$ & $3,854,600$ & 513.0 & 11543400 & - & 2416670 & 31 \\
\hline Aug 07 & 794,100 & $3,160,800$ & $1,983,200$ & 263.9 & - & 5938100 & 2624729 & 31 \\
\hline Sept 07 & $2,137,200$ & $8,520,800$ & $5,343,700$ & 711.2 & - & 16001700 & 2579852 & 30 \\
\hline Oct 07 & $1,864,100$ & $7,430,100$ & $4,660,900$ & 620.2 & - & 13955100 & 2728077 & 31 \\
\hline Nov 07 & 817,000 & $3,259,700$ & $2,042,200$ & 272.0 & - & 6118900 & 2597930 & 30 \\
\hline \multicolumn{9}{|l|}{ Column } \\
\hline Totals & $12,040,800$ & $48,498,900$ & $30,414,600$ & 4,042 & $48,940,500$ & $42,013,800$ & $28,320,380$ & 329 \\
\hline
\end{tabular}

\footnotetext{
a Combined total production from wells GWEX1-GWEX4: 119,274,680 gal.

b Wells GWEX1-GWEX3 operate simultaneously.

c Total production to wetlands: $90,954,300$ gal.

d Unit not in operation.
}

\subsection{Production by Wells GWEX1-GWEX3}

Wells GWEX1-GWEX3 are equipped with electronically controlled pump drive units linked to digital flow meters that automatically and continuously adjust the flow from each well to maintain user-specified pumping rates. During this review period, the programmed flow rates for these wells were as follows: 
- $\quad$ GWEX1, 50 gpm

- $\quad$ GWEX2, 200 gpm

- $\quad$ GWEX3, 125 gpm

The selected rates were achieved, within $\pm 1 \mathrm{gpm}$, throughout the review period (Table 4.2).

Wells GWEX1-GWEX3 were pumped for approximately 4,042 hr during the review period, and they discharged approximately 91 million gallons (280 acre-feet) of treated water to the North Lake Basin wetlands. This represents an increase of 6.6 million gallons (7.8\%) over the previous reporting period. Operation of the wells for significant periods during both the early spring (March) and fall (October) of 2007 compensated for relatively intermittent operation (in comparison to 2006) during an unusually wet summer in 2007. The treated groundwater was discharged roughly equally to the northern and southern wetlands subbasins, with the approval of the NGPC.

\subsection{Production by Well GWEX4}

Measured groundwater pumping rates (determined by an in-line flow meter) at GWEX4 remained relatively stable, ranging from approximately $54 \mathrm{gpm}$ to $64 \mathrm{gpm}$, throughout the review period. The lower of these rates occurred immediately after operation of the well was resumed after the May 2007 shutdown period (Section 3.2). A minor adjustment to the electronic pump control unit was performed in June to return GWEX4 to a targeted flow rate of 60-64 gpm. The volume of groundwater pumped in any one complete month (Table 4.1) ranged from about 1.9 million gallons to 2.8 million gallons. Approximately 28.3 million gallons ( 86.8 acre-feet) of groundwater was treated and discharged by GWEX4 during the review period, at a net average pumping rate of $58.9 \mathrm{gpm}$. This represents a decrease of 1.3 million gallons (4.3\%) compared to the previous review period. 
TABLE 4.2 Comparison of actual well production rates and target rates.

\begin{tabular}{ccc}
\hline & \multicolumn{2}{c}{ Pumping Rate (gpm) } \\
\cline { 2 - 3 } Well & Target & Actual (Net Average) \\
& & \\
\hline & & \\
GWEX1 & 50 & 49.6 \\
GWEX2 & 200 & 199.99 \\
GWEX3 & 125 & 125.41 \\
GWEX4 & $60-64$ & 58.9 \\
& & \\
\hline
\end{tabular}




\section{Groundwater Treatment Results}

Treated groundwater at Utica is discharged under a National Pollutant Discharge Elimination System (NPDES) Permit, number NE0137456, issued by the Nebraska Department of Environmental Quality (NDEQ) on October 1, 2004.

To comply with the NPDES permit, samples of treated groundwater are collected monthly

- At the outlet of the air stripping unit at GWEX4 and

- From the spray discharge at each of the irrigation treatment units (during months of operation).

The samples are analyzed to determine (1) the residual concentrations of carbon tetrachloride in the treated groundwater and (2) the $\mathrm{pH}$ of the effluent. The results of these analyses are reported to the NDEQ quarterly.

The discharges of treated groundwater at Utica are considered by the NDEQ to contribute to the surface waters of the state. On this basis, NDEQ has specified the following compliance limits for the outfall from each treatment unit:

- A target maximum residual carbon tetrachloride concentration of $44.2 \mu \mathrm{g} / \mathrm{L}$

- An acceptable $\mathrm{pH}$ range of 6.5 to 9.0

In conjunction with the compliance sampling, Argonne collects monthly samples of the untreated groundwater from each extraction well. The samples are analyzed for volatile organic compounds (VOCs) to enable estimation of the following:

- Carbon tetrachloride removal efficiencies for the treatment units

- Quantities of carbon tetrachloride removed from the contaminated aquifer 
The results of the sampling and analyses during the review period are summarized in Tables 5.1 and 5.2. System performance during the three years of operation is summarized in Section 7.

\subsection{Results for Wells GWEX1-GWEX3, with Treatment by Spray Irrigation}

The concentrations of carbon tetrachloride found in the untreated groundwater from extraction wells GWEX2 and GWEX3 generally decreased during the review period (Table 5.1), despite temporary rises observed during the April and May 2007 sampling events. Carbon tetrachloride concentrations at GWEX2 ranged from $51 \mu \mathrm{g} / \mathrm{L}$ to $90 \mu \mathrm{g} / \mathrm{L}$, while at GWEX3 the levels ranged from $42 \mu \mathrm{g} / \mathrm{L}$ to $103 \mu \mathrm{g} / \mathrm{L}$.

Observed carbon tetrachloride levels at upgradient extraction well GWEX1 were erratic during the review period, showing no apparent correlation to the concentrations observed at GWEX2 and GWEX3. Carbon tetrachloride concentrations in untreated groundwater at GWEX1 ranged from lower values of 10-24 $\mu \mathrm{g} / \mathrm{L}$ in March-April 2007, to 63-66 $\mu \mathrm{g} / \mathrm{L}$ in May-June 2007, and to a higher value of $69 \mu \mathrm{g} / \mathrm{L}$ in November 2007.

The untreated groundwater produced from wells GWEX1-GWEX3 is combined into a single stream for conveyance to the wetlands via a common pipeline. This combined flow is also sampled monthly as an indicator of the weighted average concentration of carbon tetrachloride in the untreated groundwater supplied to the spray irrigation treatment units. The measured concentrations in the combined flow during the present reporting period (December 2006November 2007) varied from $48 \mu \mathrm{g} / \mathrm{L}$ to $90 \mu \mathrm{g} / \mathrm{L}$. For comparison, the measured concentrations in the combined flow during the previous reporting period (December 2005-November 2006) were higher, ranging from $71 \mu \mathrm{g} / \mathrm{L}$ to $139 \mu \mathrm{g} / \mathrm{L}$. Performance data for previous reporting periods are summarized in Section 7.

In the present reporting period, the temporal variations in concentration observed in the combined flow stream generally mirrored those observed at wells GWEX2 and GWEX3, which together contributed approximately $87 \%$ of the total discharge from the extraction well system (Table 4.1). 
TABLE 5.1 Analytical results for carbon tetrachloride in untreated groundwater samples and treated effluent samples in December 2006November 2007.

\begin{tabular}{|c|c|c|c|c|c|c|c|c|c|c|c|c|c|c|}
\hline \multirow[b]{3}{*}{ Month } & \multicolumn{14}{|c|}{ Carbon Tetrachloride Concentration $(\mu \mathrm{g} / \mathrm{L})$} \\
\hline & \multicolumn{4}{|c|}{ GWEX1-GWEX3 Untreated } & \multicolumn{4}{|c|}{ North Spray Unit Effluent } & \multicolumn{4}{|c|}{ South Spray Unit Effluent } & \multirow{2}{*}{$\begin{array}{l}\text { GWEX4 } \\
\text { Untreated }\end{array}$} & \multirow{2}{*}{$\begin{array}{l}\text { Stripper } \\
\text { Effluent }\end{array}$} \\
\hline & GWEX1 & GWEX2 & GWEX3 & Mixed $^{\mathrm{a}}$ & West $^{\mathrm{b}}$ & Center ${ }^{b}$ & East $^{\mathrm{b}}$ & $\operatorname{Max}{ }^{C}$ & West $^{b}$ & Center ${ }^{b}$ & East $^{b}$ & $\operatorname{Max}^{\mathrm{C}}$ & & \\
\hline Dec 06 & 52 & 72 & 88 & $68-73$ & 3.7 & $0.3 \mathrm{Jd}$ & $0.5 \mathrm{~J}$ & $N D^{e}$ & $-{ }^{f}$ & - & - & - & $28-299$ & ND \\
\hline Jan 07 & $44-47$ & 69 & 91 & 70 & $0.5 \mathrm{~J}$ & $0.5 \mathrm{~J}$ & $0.5 \mathrm{~J}$ & $0.4 \mathrm{~J}$ & - & - & - & - & $30-30$ & ND \\
\hline Feb 07 & - & - & - & - & - & - & - & - & - & - & - & - & $29-35$ & ND \\
\hline Mar 07 & $23-24$ & 51 & 89 & 53 & $0.4 \mathrm{~J}$ & ND & 1.1 & 1.1 & - & - & - & - & $39-43$ & ND \\
\hline Apr 07 & 10 & 78 & 103 & $79-83$ & ND & $0.4 \mathrm{~J}$ & $0.6-0.7 \mathrm{~J}$ & $0.8 \mathrm{~J}$ & - & - & - & - & $25-30$ & ND \\
\hline May 07 & 63 & $82-90$ & 101 & 90 & $0.4 \mathrm{~J}$ & $0.6 \mathrm{~J}$ & 1 & ND & - & - & - & - & & ND \\
\hline Jun 07 & 66 & 75 & 68 & 70 & 1.2 & 1.1 & $0.6 \mathrm{~J}$ & $0.3 \mathrm{~J}$ & - & - & - & - & 28 & ND \\
\hline Jul 07 & 38 & 78 & 74 & $69-70$ & $0.5 \mathrm{~J}$ & $0.5 \mathrm{~J}$ & 1.4 & $0.2-0.3 \mathrm{~J}$ & - & - & - & - & 29 & ND \\
\hline Aug 07 & 41 & 56 & 54 & 56 & - & - & - & - & ND & 1.1 & $0.4 \mathrm{~J}$ & ND & $22-23$ & ND \\
\hline Sep 07 & 53 & 55 & 45 & 52 & - & - & - & - & ND & ND & $0.4 \mathrm{~J}$ & ND & 23 & ND \\
\hline Oct 07 & 54 & $52-53$ & 42 & 50 & - & - & - & - & $0.2 \mathrm{~J}$ & 1.3 & $0.5 \mathrm{~J}$ & $0.1 \mathrm{~J}$ & 20 & ND \\
\hline Nov 07 & 69 & 54 & $43-51$ & 48 & - & - & - & - & 1.9 & 1.1 & 1.1 & ND & 24 & ND \\
\hline
\end{tabular}

a Analytical results for samples from the combined flows of GWEX1-GWEX3.

b Samples of spray collected below the center point of the respective irrigation span.

c Samples of spray collected at the estimated location of maximum spray outfall.

d Qualifier $\mathrm{J}$ indicates an estimated concentration below the quantitation limit of $1 \mu \mathrm{g} / \mathrm{L}$ for the purge-and-trap method.

e ND, not detected at a method detection limit of $0.1 \mu \mathrm{g} / \mathrm{L}$.

$f$ Unit not in operation.

9 Ranges of values represent both primary samples and quality control replicates and duplicates. 
TABLE 5.2 Values for $\mathrm{pH}$ in untreated groundwater samples and treated effluent samples in December 2006-November 2007.

\begin{tabular}{|c|c|c|c|c|c|c|c|c|}
\hline \multirow[b]{3}{*}{ Month } & \multicolumn{8}{|c|}{$\mathrm{pH}$} \\
\hline & \multicolumn{4}{|c|}{ GWEX1-GWEX3 Untreated } & \multirow{2}{*}{$\begin{array}{l}\text { North } \\
\text { Spray } \\
\text { Unit }^{\mathrm{b}}\end{array}$} & \multirow{2}{*}{$\begin{array}{l}\text { South } \\
\text { Spray } \\
\text { Unit }^{b}\end{array}$} & \multirow{2}{*}{$\begin{array}{l}\text { GWEX4 } \\
\text { Untreated }\end{array}$} & \multirow{2}{*}{$\begin{array}{l}\text { Stripper } \\
\text { Effluent }\end{array}$} \\
\hline & GWEX1 & GWEX2 & GWEX3 & Mixed $^{\mathrm{a}}$ & & & & \\
\hline Dec 06 & $6.78-6.79$ & $6.71-6.73$ & $6.65-6.66$ & $6.65-6.67$ & 7.87-8.03 & $-^{c}$ & $6.36-6.43^{d}$ & $7.79-7.89^{d}$ \\
\hline Jan 07 & $7.50-7.56$ & 7.39-7.46 & $N A^{e}$ & 7.54-7.91 & $7.59-8.35$ & - & 6.67 & 7.94-7.98 \\
\hline Feb 07 & - & - & - & - & - & - & $7.23-7.25$ & $8.11-8.33$ \\
\hline Mar 07 & $6.56-6.59$ & $6.52-6.55$ & $6.53-6.54$ & $6.42-6.43$ & $7.25-7.75$ & - & $6.44-6.49$ & 7.92-7.95 \\
\hline Apr 07 & $6.80-6.82$ & $6.73-6.74$ & $6.64-6.67$ & $6.70-6.72$ & 7.73-7.86 & - & $6.35-6.42$ & 7.82-7.89 \\
\hline May 07 & $6.95-6.99$ & $6.85-6.88$ & $6.85-6.86$ & $6.88-6.91$ & 7.09-7.74 & - & - & - \\
\hline Jun 07 & 7.08-7.09 & 7.20-7.32 & 7.07 & $7.00-7.03$ & $8.29-8.36$ & - & $6.96-7.03$ & 8.03-8.24 \\
\hline Jul 07 & $6.69-6.72$ & $6.61-6.62$ & 6.56 & $6.59-6.62$ & $7.68-7.91$ & - & $6.27-6.35$ & 7.82-7.84 \\
\hline Aug 07 & $6.77-6.78$ & $6.67-6.70$ & $6.65-6.66$ & $6.70-6.78$ & - & $7.83-8.28$ & $6.37-6.47$ & 7.88-7.94 \\
\hline Sep 07 & 7.09-7.19 & $6.98-7.00$ & $6.90-7.04$ & 6.97 & - & $8.26-8.31$ & $6.37-6.83$ & $8.19-8.27$ \\
\hline Oct 07 & $7.10-7.13$ & 7.01-7.03 & $6.96-6.97$ & 7.03 & - & $8.15-8.31$ & $6.92-6.93$ & $8.11-8.29$ \\
\hline Nov 07 & $7.09-7.11$ & $6.99-7.01$ & $6.96-6.95$ & $6.98-7.04$ & - & $7.99-8.20$ & $6.88-6.95$ & $8.16-8.30$ \\
\hline
\end{tabular}

a Ranges of values for multiple measurements of the combined flows from GWEX1-GWEX3.

b Ranges of values for spray samples collected at multiple locations at the discharge site.

c Unit not in operation.

d Range of values for multiple measurements at this location.

e NA, no analysis.

Treated groundwater sprayed from the irrigation units is collected for analysis at the following four locations at the treatment site during each sampling event:

- Beneath the center point of the "west" irrigation span

- Beneath the center point of the "center" irrigation span

- Beneath the center point of the "east" irrigation span

- At a fourth location visually chosen to reflect the estimated site of maximum spray outfall ("max" value; position varying from month to month; based on prevailing wind and spray conditions at the time of sampling) 
The results summarized in Table 5.1 show that the concentrations of all spray samples collected during the review period were below the maximum contaminant level of $5.0 \mu \mathrm{g} / \mathrm{L}$ promulgated by the U.S. Environmental Protection Agency for carbon tetrachloride in drinking water. The maximum carbon tetrachloride level identified for a single sample in spray discharged from the irrigation treatment units was $3.7 \mu \mathrm{g} / \mathrm{L}$. The average concentration of carbon tetrachloride in the treated groundwater discharged to the wetlands was $0.61 \mu \mathrm{g} / \mathrm{L}$. The corresponding concentrations in the previous reporting period were $6.9 \mu \mathrm{g} / \mathrm{L}$ (maximum) and $0.91 \mu \mathrm{g} / \mathrm{L}$ (average). Performance in previous review periods is summarized in Section 7.

During the present review period, the concentrations of carbon tetrachloride in all spray samples were below the maximum target concentration $(44.2 \mu \mathrm{g} / \mathrm{L})$ allowed under the NPDES permit, by roughly an order of magnitude.

The analytical results for the groundwater and spray samples suggest the following minimum carbon tetrachloride removal efficiency values for the spray irrigation treatment process during this review period:

- More than $95 \%$ (based on data for individual samples)

- Approximately $98 \%$ (based on the average concentration delivered to the wetlands during the review period)

The results of $\mathrm{pH}$ measurements recorded for samples of the treated spray discharge are presented in Table 5.2. In all cases, the observed $\mathrm{pH}$ levels (7.09 to 8.36) were within the acceptable range (6.5 to 9.0) specified under the NPDES permit.

\subsection{Results for Well GWEX4, with Treatment by Air Stripping}

From December 2006 through July 2007, carbon tetrachloride concentrations in the untreated groundwater produced by GWEX4 (Table 5.1) were relatively stable ( $25 \mu \mathrm{g} / \mathrm{L}$ to $43 \mu \mathrm{g} / \mathrm{L})$. Consistently lower concentrations $(20 \mu \mathrm{g} / \mathrm{L}$ to $24 \mu \mathrm{g} / \mathrm{L})$ were detected at this location during the later part of the review period. Carbon tetrachloride was not detected in the effluent from the air stripping unit throughout the review period, indicating a carbon tetrachloride removal efficiency of $>99 \%$ for this process. Measured $\mathrm{pH}$ levels in all samples of the air 
stripper effluent (7.79 to 8.33; Table 5.2) were within the acceptable range (6.5 to 9.0) specified under the NPDES permit. Comparisons with previous review periods are in Section 7.

\subsection{Estimated Removal of Carbon Tetrachloride from the Utica Aquifer}

The groundwater production and carbon tetrachloride concentration data presented in Tables 4.1 and 5.1, respectively, can be used to estimate the total quantity of carbon tetrachloride extracted by wells GWEX1-GWEX4 from December 1, 2006, to November 30, 2007. The results of these calculations, summarized in Table 5.3, indicate that approximately $25 \mathrm{~kg}$ (4.1 gal) of carbon tetrachloride was removed from the Utica aquifer during the present (December 2006-November 2007) review period. In the previous period (December 2005November 2006), approximately $34 \mathrm{~kg}$ (5.6 gal) of carbon tetrachloride was removed.

The somewhat lower quantity of carbon tetrachloride removed in the present review period than in the previous period primarily reflects a general decrease in the contaminant concentrations observed in untreated groundwater at extraction wells GWEX2-GWEX4 (Sections 5.1 and 5.4), rather than a decrease in the volumetric throughput or contaminant removal efficiency of the groundwater treatment systems. Comparisons with previous review periods are in Section 7.

\subsection{Sampling of Monitoring Wells and Apparent Carbon Tetrachloride Concentration Trends in the Utica Groundwater}

Table 5.4 presents a summary of construction data for the monitoring wells, along with the results of groundwater sampling and analyses for VOCs in October 2006 and three months during the current review period. Complete monitoring data for wells MW1-MW4, since sampling at these points began in September 2005, are depicted in Figure 5.1. Figures 5.2-5.5 summarize the carbon tetrachloride concentrations measured at GWEX1-GWEX4, respectively, since the routine operation and sampling of these wells began in November 2004.

Carbon tetrachloride concentrations at monitoring wells MW2, MW3, and MW4 (Figure 5.1) have been relatively stable, with no persistent rising or falling trends. In contrast, concentrations at monitoring well MW1 have been less stable. 
TABLE 5.3 Estimation of carbon tetrachloride removed from the Utica aquifer in December 2006-November 2007. ${ }^{a}$

\begin{tabular}{|c|c|c|c|c|c|c|c|c|}
\hline \multirow[b]{4}{*}{ Month } & \multicolumn{4}{|c|}{ GWEX1-GWEX3 } & \multicolumn{4}{|c|}{ GWEX4 } \\
\hline & \multirow{2}{*}{\multicolumn{2}{|c|}{ Groundwater Extracted }} & \multicolumn{2}{|c|}{ Carbon Tetrachloride } & & & \multicolumn{2}{|c|}{ Carbon Tetrachloride } \\
\hline & & & & $\begin{array}{l}\text { Calculated } \\
\text { Amount }\end{array}$ & \multicolumn{2}{|c|}{$\begin{array}{c}\text { Groundwater } \\
\text { Extracted }\end{array}$} & \multirow{2}{*}{$\begin{array}{l}\text { Concentration } \\
\qquad(\mu \mathrm{g} / \mathrm{L})\end{array}$} & \multirow{2}{*}{$\begin{array}{l}\text { Calculated } \\
\text { Amount } \\
\text { Removed } \\
(\mathrm{kg})\end{array}$} \\
\hline & (gal) & $(\mathrm{L})$ & $(\mu \mathrm{g} / \mathrm{L})$ & $(\mathrm{kg})$ & (gal) & $(\mathrm{L})$ & & \\
\hline Dec 06 & 2147500 & 8130435.0 & 70.5 & 0.6 & 2697174 & 10211501 & 28.5 & 0.3 \\
\hline Jan 07 & 404200 & 1530301.2 & 70 & 0.1 & 2708244 & 10253412 & 30 & 0.3 \\
\hline Feb 07 & $-c$ & - & - & 0.0 & 2506360 & 9489079 & 32 & 0.3 \\
\hline Mar 07 & 7592700 & 28745962.2 & 53 & 1.5 & 2785704 & 10546675 & 41 & 0.4 \\
\hline Apr 07 & 4941200 & 18707383.2 & 81 & 1.5 & 2744008 & 10388814 & 27.5 & 0.3 \\
\hline May 07 & 12827800 & 48566050.8 & 90 & 4.4 & - & - & & 0.0 \\
\hline Jun 07 & 9483700 & 35905288.2 & 70 & 2.5 & 1931632 & 7313159 & 28 & 0.2 \\
\hline Jul 07 & 11543400 & 43703312.4 & 69.5 & 3.0 & 2416670 & 9149513 & 29 & 0.3 \\
\hline Aug 07 & 5938100 & 22481646.6 & 56 & 1.3 & 2624729 & 9937224 & 22.5 & 0.2 \\
\hline Sep 07 & 16001700 & 60582436.2 & 52 & 3.2 & 2579852 & 9767320 & 23 & 0.2 \\
\hline Oct 07 & 13955100 & 52834008.6 & 50 & 2.6 & 2728077 & 10328500 & 20 & 0.2 \\
\hline Nov 07 & 6118900 & 23166155.4 & 48 & 1.1 & 2597930 & 9835763 & 24 & 0.2 \\
\hline TOTAL & & & & 21.8 & & & & 3.0 \\
\hline
\end{tabular}

a Total carbon tetrachloride removed from the aquifer: $24.8 \mathrm{~kg}$.

b Concentration in untreated samples of the combined flow from wells GWEX1-GWEX3.

c Unit not in operation. 
TABLE 5.4 Well construction data and analytical results for carbon tetrachloride in groundwater samples from the permanant monitoring wells.

\begin{tabular}{|c|c|c|c|c|c|c|}
\hline \multirow[b]{3}{*}{ Well } & \multicolumn{2}{|c|}{ Depth (ft BGL) } & & & & \\
\hline & \multirow[b]{2}{*}{ Total } & \multirow{2}{*}{$\begin{array}{l}\text { Screened } \\
\text { Interval }\end{array}$} & \multicolumn{4}{|c|}{ Carbon Tetrachloride $(\mu \mathrm{g} / \mathrm{L})$} \\
\hline & & & Oct 06 & Feb 07 & Jun 07 & Oct 07 \\
\hline SB48 & 98.5 & $83.5-93.5$ & $N^{a}$ & ND & ND & ND \\
\hline SB71 & 94.2 & $84-94$ & ND & $0.5 \mathrm{Jb}$ & ND & $0.2 \mathrm{~J}$ \\
\hline SB72 & 122.3 & 82.6-112.6 & 1.8 & 1.2 & 1.0 & $0.8 \mathrm{~J}$ \\
\hline MW1 & 105 & $85-100$ & 130 & 170 & 542 & 328 \\
\hline MW2 & 115 & $90-110$ & 17 & 16 & 11 & 17 \\
\hline MW3 & 125 & $100-120$ & 58 & $74-82^{c}$ & 89 & 37 \\
\hline MW4 & 125 & $100-120$ & 4.9 & 8.3 & 37 & 3.2 \\
\hline
\end{tabular}

a ND, not detected at a method detection limit of $0.1 \mu \mathrm{g} / \mathrm{L}$.

b Qualifier J indicates an estimated concentration below the quantitation limit of $1 \mu \mathrm{g} / \mathrm{L}$ for the purge-and-trap method.

c Ranges of values represent both primary samples and quality control replicates and duplicates.

Among the extraction wells, carbon tetrachloride concentrations at GWEX1 (Figure 5.2) have not exhibited a decreasing trend, though concentrations at extraction wells GWEX2, GWEX3, and GWEX4 (Figures 5.3-5.5, respectively) do appear to be declining slowly, along generally consistent trends.

Wells MW1 and GWEX1 are located, respectively, on and near the former CCC/USDA facility property (Figure 2.1). The observed carbon tetrachloride concentrations at GWEX1 have been highly variable (Figure 5.2), but generally they appear to reflect a slowly increasing trend. Carbon tetrachloride levels at well MW1 (Figure 5.1) have consistently been greater than those at the downgradient monitoring wells (MW2, MW3, MW4, SB48, SB71, SB72; Figure 2.1). The concentrations at MW1 increased significantly (to a maximum of $542 \mu \mathrm{g} / \mathrm{L}$ ) in June-October 2007.

Together, these data for MW1 and GWEX1 might reflect a continuing or intermittent influence of localized carbon tetrachloride contribution to the upgradient shallow groundwater from residual contamination in the soils beneath the former CCC/USDA facility. Further monitoring will be required to evaluate this hypothesis; however, the stable or decreasing contaminant levels observed at all of the downgradient sampling locations suggest that GWEX1 is presently operating effectively as an upgradient capture well. 


\subsection{Evaluation of Groundwater Inorganic Geochemistry}

In accord with the approved Monitoring Plan for Utica (Argonne 2004), samples of the untreated groundwater from individual extraction wells GWEX1-GWEX4, the combined flow from wells GWEX1-GWEX3 that is supplied to the spray irrigation treatment units, and the (treated) effluent from the air stripper at GWEX4 were collected in October 2007 and submitted for inorganic geochemical analyses. The results of the analyses are in Table 5.5, together with equivalent data obtained for these sampling locations upon start-up of the aquifer restoration program in November 2004 and again in October 2006. (No samples were collected for inorganic geochemical analyses in 2005.)

The October 2007 results indicate no substantial changes (since restoration began) in the geochemistry of the groundwater produced by the extraction wells, treated, and discharged to the surface near Utica and to the North Lake Basin Wetlands. Slight increases in the concentrations of sodium were observed at wells GWEX2-GWEX4 in 2007. In addition, slight increases in the concentrations of sodium, calcium, and chloride (possible constituents of road salts) have been observed at most of the sampling locations since 2004. An approximate doubling in the apparent concentration of sulfate (from $\sim 34 \mathrm{mg} / \mathrm{L}$ in 2004 to $\sim 64 \mathrm{mg} / \mathrm{L}$ in 2006) was observed in both the untreated and treated groundwater samples from well GWEX4. Sulfate concentrations at GWEX4 decreased slightly in 2007 but remained higher than those originally detected at this well in 2004. 
TABLE 5.5 Comparison of inorganic geochemical results for untreated groundwater samples and treated effluent samples

Concentration (mg/L)

\begin{tabular}{|c|c|c|c|c|c|c|c|c|c|c|c|c|c|c|c|c|c|c|}
\hline \multirow[b]{3}{*}{ Analyte } & \multicolumn{18}{|c|}{ Concentration (mg/L) } \\
\hline & \multicolumn{3}{|c|}{ GWEX1 } & \multicolumn{3}{|c|}{ GWEX2 } & \multicolumn{3}{|c|}{ GWEX3 } & \multicolumn{3}{|c|}{ GWEX1-GWEX3 } & \multicolumn{3}{|c|}{ GWEX4 Untreated } & \multicolumn{3}{|c|}{ GWEX4 Effluent } \\
\hline & Nov. 2004 & Oct. 2006 & Oct. 2007 & Nov. 2004 & Oct. 2006 & Oct-07 & Nov. 2004 & Oct. 2006 & Oct. 2007 & Nov. 2004 & Oct. 2006 & Oct. 2007 & Nov. 2004 & Oct. 2006 & Oct. 2007 & Nov. 2004 & Oct. 2006 & Oct. 2007 \\
\hline Total Alkalinity & $-^{a}$ & 266 & - & - & 275 & - & - & 255 & - & - & 262 & - & - & 287 & - & - & 287 & - \\
\hline Aluminum & $<0.2^{b}$ & $<0.2$ & $<0.2$ & $<0.2$ & $<0.2$ & $<0.2$ & $<0.2$ & $<0.2$ & $<0.2$ & $<0.2$ & $<0.2$ & $<0.2$ & $<0.2$ & $<0.2$ & $<0.2$ & $<0.2$ & $<0.2$ & $<0.2$ \\
\hline Calcium & 67.6 & 84.9 & 80.4 & 78.6 & 87.5 & 88.5 & 92.8 & 89.4 & 100 & 82.2 & 96.9 & 90.7 & 89.4 & 109 & 105 & 85.7 & 106 & 108 \\
\hline Chloride & 6.93 & 13.2 & $11 \mathrm{H}^{\mathrm{C}}$ & 11.4 & 24.0 & $20 \mathrm{H}$ & 25.9 & 24.0 & $21 \mathrm{H}$ & 15.5 & 21.9 & $19 \mathrm{H}$ & 18.3 & 28.9 & $24 \mathrm{H}$ & 18.7 & 29.3 & $27 \mathrm{H}$ \\
\hline & $<0.1$ & $<0.1$ & $<0.1$ & $<0.1$ & $<0.1$ & $<0.1$ & $<0.1$ & $<0.1$ & $<0.1$ & $<0.1$ & $<0.1$ & $<0.1$ & $<0.1$ & $<0.1$ & $<0.1$ & $<0.1$ & $<0.1$ & $<0.1$ \\
\hline Magnesium & 11.6 & 13.0 & 13.3 & 13.4 & 13.6 & 15 & 16.2 & 13.9 & 16.9 & 14.3 & 15.1 & 15.3 & 14.8 & 17.0 & 17.7 & 14.8 & 16.5 & 18 \\
\hline Manganese & $<0.015^{b}$ & $<0.015$ & $<0.015$ & $<0.015$ & $<0.015$ & $<0.015$ & $<0.015$ & $<0.015$ & $<0.015$ & $<0.015$ & $<0.015$ & $<0.015$ & $<0.015$ & $<0.015$ & $<0.015$ & $<0.015$ & $<0.015$ & $<0.015$ \\
\hline Phosphate & 0.363 & 0.305 & $0.180 \mathrm{H}$ & 0.777 & 0.307 & $0.250 \mathrm{H}$ & 0.391 & 0.299 & $0.250 \mathrm{H}$ & 0.218 & 0.311 & $0.210 \mathrm{H}$ & 0.332 & 0.293 & $0.250 \mathrm{H}$ & $<0.2$ & 0.298 & $0.250 \mathrm{H}$ \\
\hline Phosphorus & 0.285 & 0.273 & 0.298 & 0.285 & 0.279 & 0.311 & 0.264 & 0.318 & 0.312 & 0.279 & 0.287 & 0.308 & 0.278 & 0.255 & 0.283 & 0.283 & 0.275 & 0.292 \\
\hline Potassium & 5.66 & 6.27 & 5.19 & 6.00 & 6.33 & 5.87 & 6.94 & 6.43 & 6.36 & 6.27 & 6.85 & 5.97 & 6.58 & 7.10 & 6.29 & 6.6 & 6.86 & 6.4 \\
\hline Silicon & 16.8 & 17.0 & 13.1 & 17.1 & 16.5 & 16.9 & 17.9 & 16.5 & 17.9 & 17.4 & 17.0 & 18.1 & 17.6 & 17.3 & 15.9 & 17.7 & 16.8 & 16.0 \\
\hline Sodium & 26.5 & 31.9 & 31.8 & 28.7 & 34.4 & 38.2 & 32.0 & 35.1 & 43.7 & 29.5 & 41.6 & 39.1 & 32.8 & 41.6 & 44.4 & 33.5 & 41 & 45.1 \\
\hline $\begin{array}{l}\text { Sulfate } \\
\text { Sulfate }\end{array}$ & $\begin{array}{l}20.5 \\
22.4\end{array}$ & $\begin{array}{l}3.9 \\
23.1\end{array}$ & $\begin{array}{l}21 \mathrm{H} \\
21.8\end{array}$ & 45.5 & 39.1 & $31 \mathrm{H}$ & 59.8 & 46.3 & $40 \mathrm{H}$ & 47.9 & 39.3 & $33 \mathrm{H}$ & 33.5 & 64.9 & $50 \mathrm{H}$ & 34.5 & 63.6 & $54 \mathrm{H}$ \\
\hline & $<0.02^{b}$ & $<0.02$ & $0.07 \mathrm{~B}^{\mathrm{d}}$ & $<0.02$ & $<0.02$ & $<0.02$ & $<0.02$ & $<0.02$ & $<0.02$ & $<0.02$ & $<0.02$ & $<0.02$ & $<0.02$ & $<0.02$ & $<0.02$ & $<0.02$ & $<0.02$ & $<0.02$ \\
\hline Nitrate (as N) & 7.57 & 10.3 & $9.1 \mathrm{H}$ & 9.76 & 15.0 & $12 \mathrm{H}$ & 17.4 & 19.5 & $17 \mathrm{H}$ & 13.3 & 15.5 & $13 \mathrm{H}$ & 14.7 & 20.5 & $16 \mathrm{H}$ & 13.3 & 20.7 & $17 \mathrm{H}$ \\
\hline Nitrate-Nitrite N & 7.91 & 9.24 & - & 9.62 & 14.7 & - & 18.2 & 17.6 & - & 12.3 & 15.5 & - & 14.1 & 20.8 & - & 14.1 & 20.5 & - \\
\hline
\end{tabular}

a No analysis.

b Analyte not identified at analytical method detection limit indicated.

c Qualifier $\mathrm{H}$ indicates that the holding time before analysis was exceeded.

d Qualifier B indicates that the analyte was detected in an associated blank sample. 
Carbon Tetrachloride Concentrations at Monitoring Wells

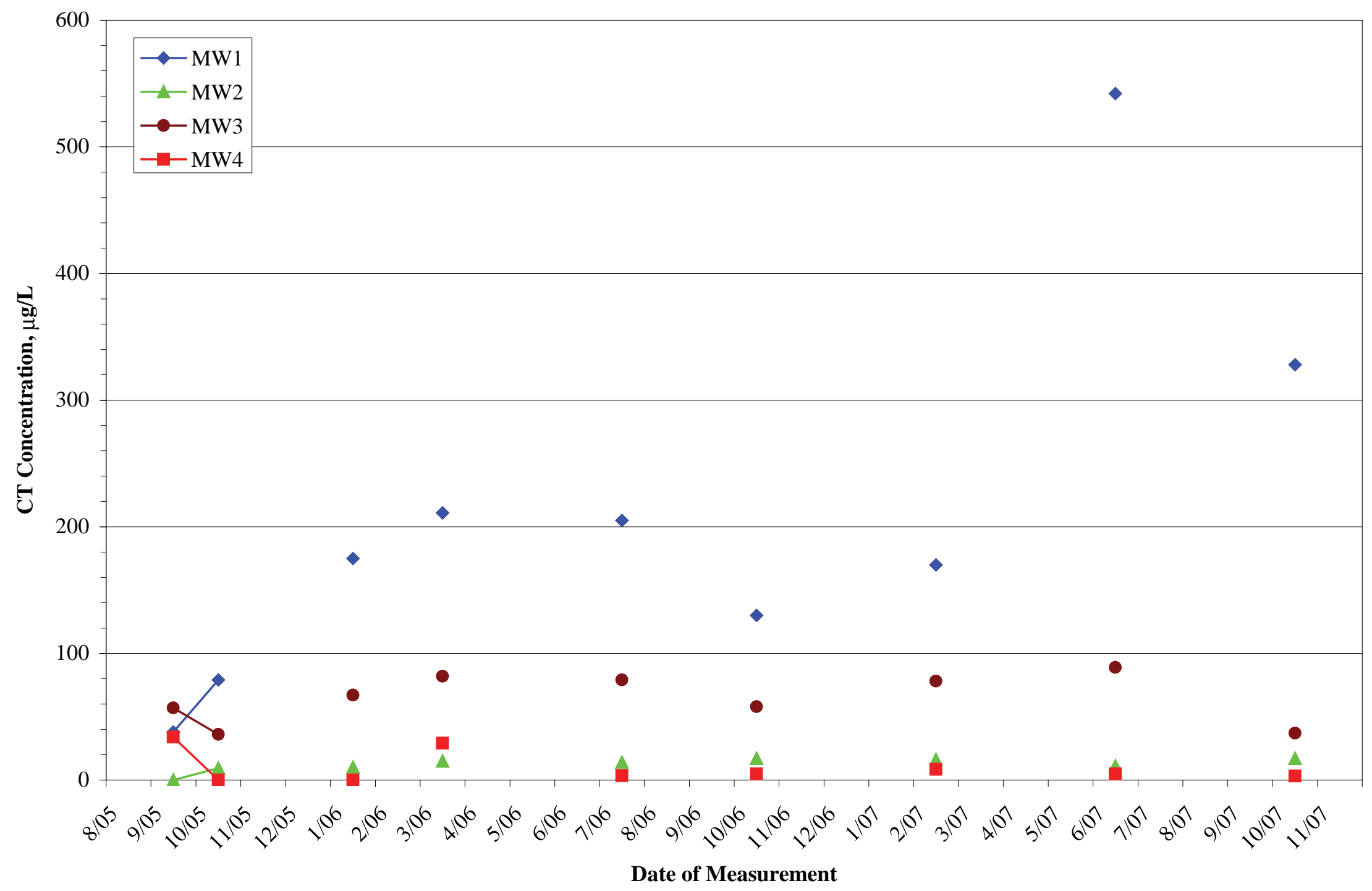

FIGURE 5.1 Carbon tetrachloride concentrations ( $\mu \mathrm{g} / \mathrm{L})$ at monitoring wells MW1-MW4, September 2005 to October 2007. 
Carbon Tetrachloride Concentrations at Extraction Well GWEX1

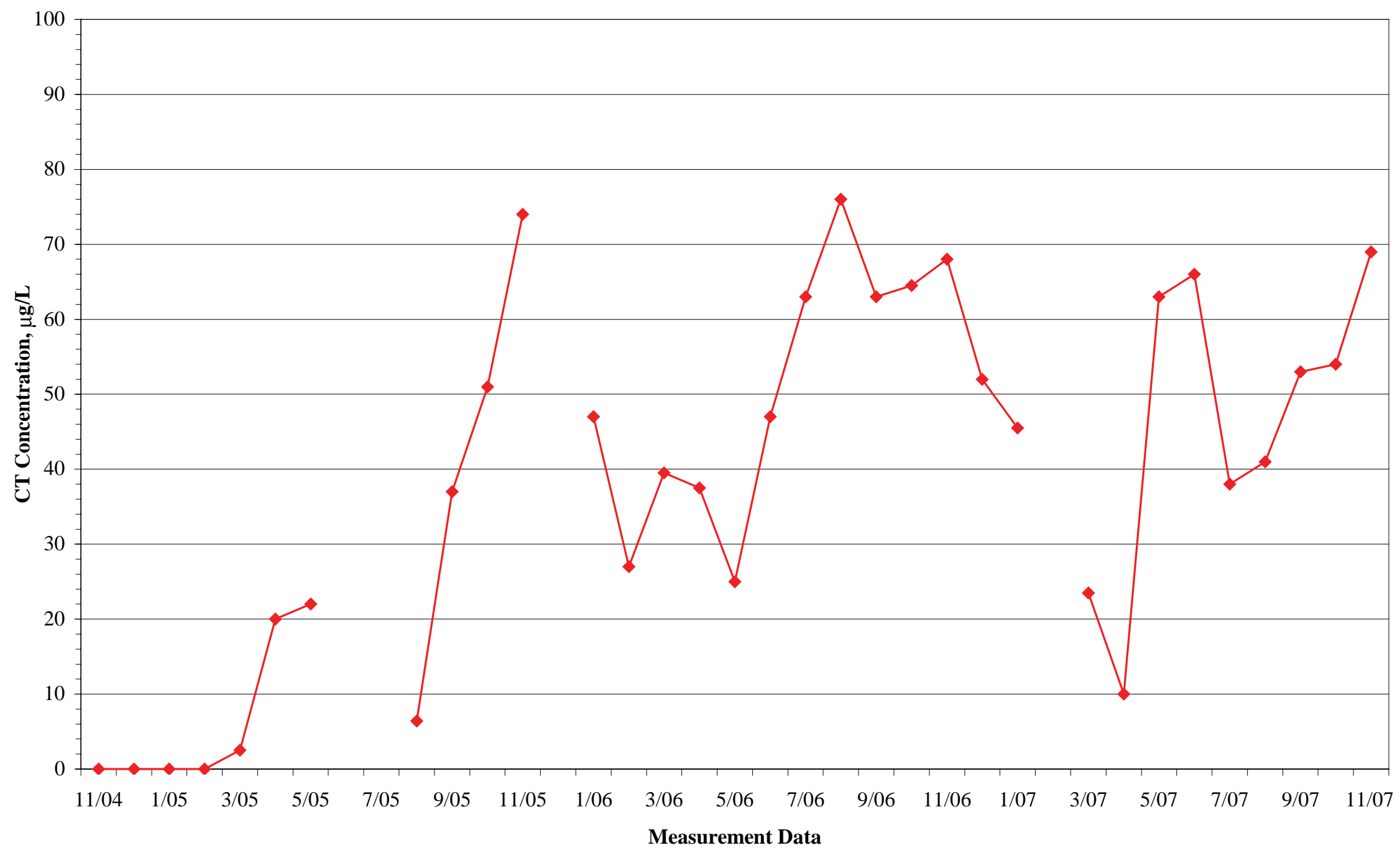

FIGURE 5.2 Carbon tetrachloride concentrations $(\mu \mathrm{g} / \mathrm{L})$ at extraction well GWEX1, November 2004 to November 2007. 
Carbon Tetrachloride Concentrations at Extraction Well GWEX2

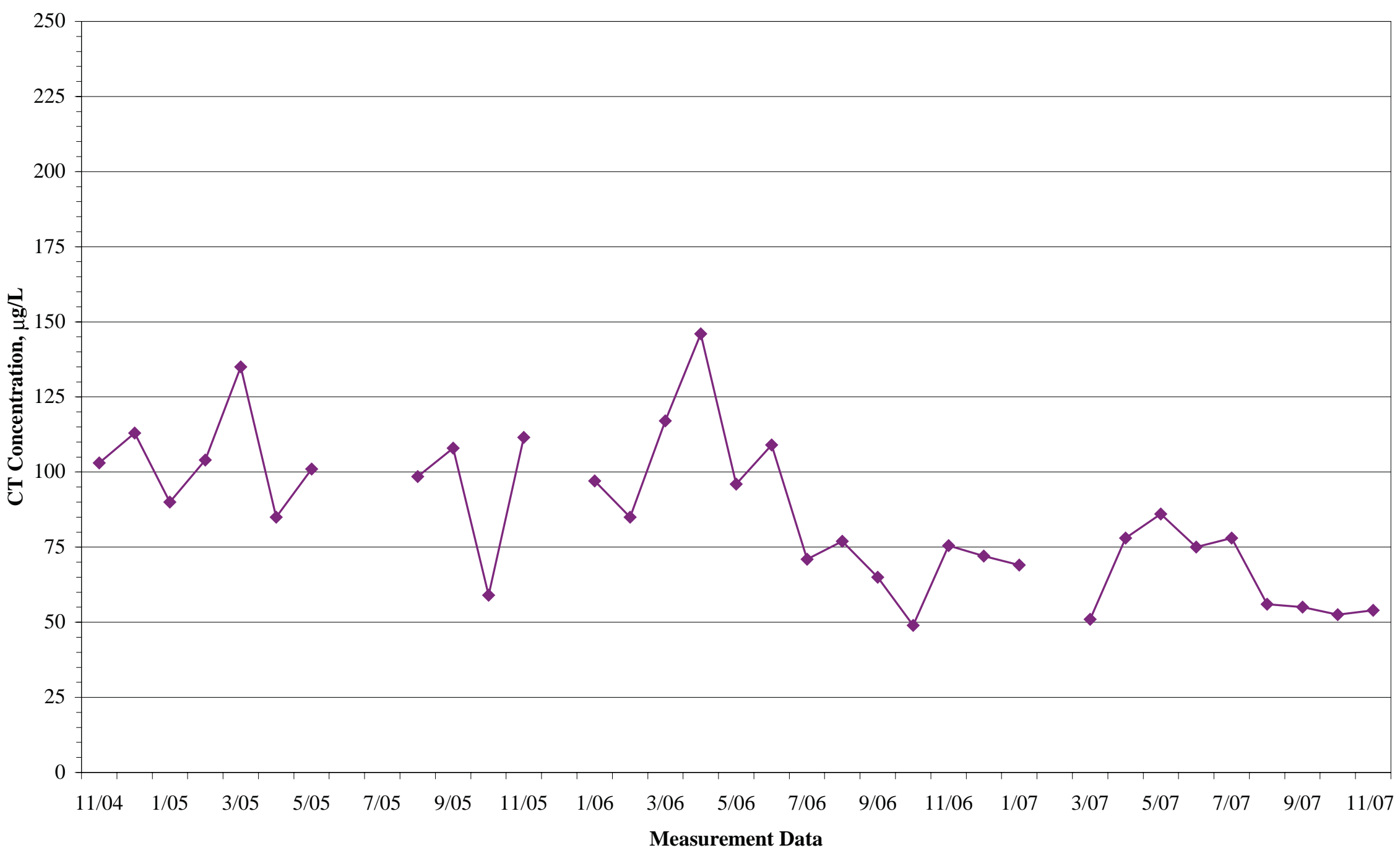

FIGURE 5.3 Carbon tetrachloride concentrations ( $\mu \mathrm{g} / \mathrm{L})$ at extraction well GWEX2, November 2004 to November 2007. 
Carbon Tetrachloride Concentrations at Extraction Well GWEX3

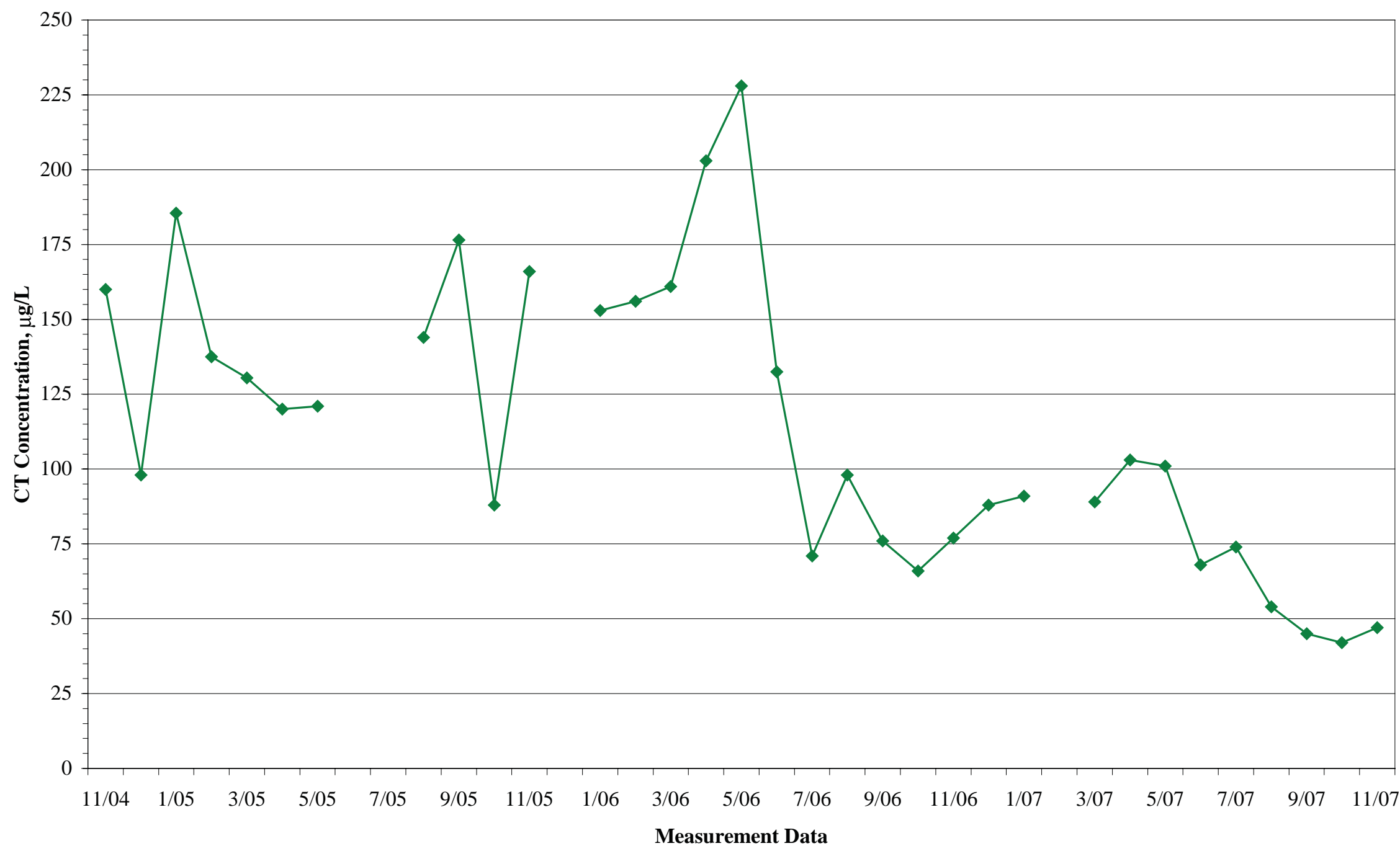

FIGURE 5.4 Carbon tetrachloride concentrations $(\mu \mathrm{g} / \mathrm{L})$ at extraction well GWEX3, November 2004 to November 2007. 
Carbon Tetrachloride Concentrations at Extraction Well GWEX4

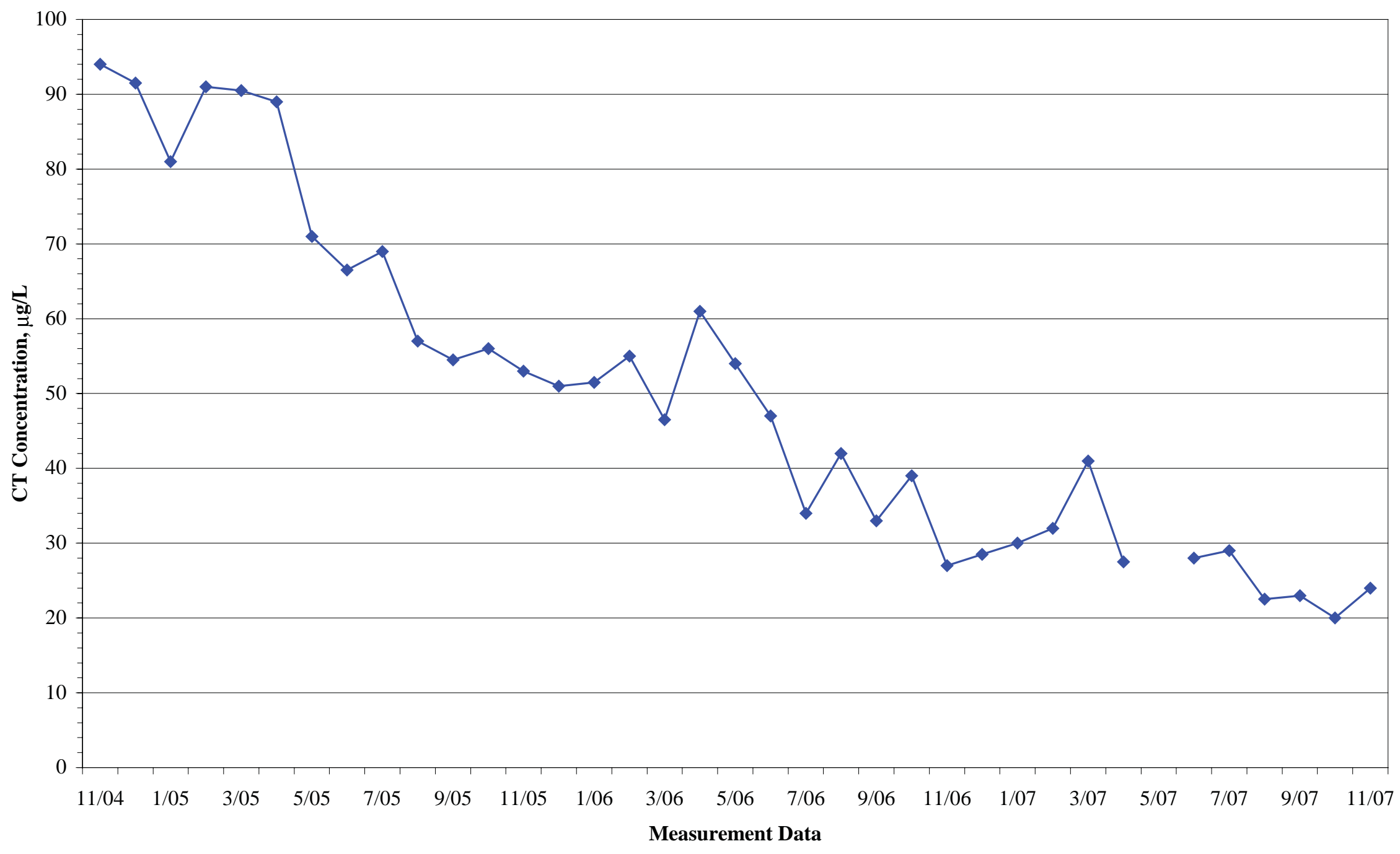

FIGURE 5.5 Carbon tetrachloride concentrations $(\mu \mathrm{g} / \mathrm{L})$ at extraction well GWEX4, November 2004 to November 2007. 


\section{Operation, Maintenance, and System Modifications}

\subsection{Wells GWEX1-GWEX3 and the Spray Irrigation Treatment Units}

Maintenance required on extraction wells GWEX1-GWEX3 during the review period involved readjustment of the electronic water level sensor at well GWEX2 to eliminate the sporadic occurrence of false alarm conditions that shut down the extraction well and spray irrigation systems.

Maintenance and repairs for the spray irrigation units and the groundwater delivery system included the following:

- $\quad$ Periodic field inspection of the units and all operating parameters.

- Seasonal mowing along the gravel access roads and pads at the north and south spray treatment sites.

- Repair of a leak at an air release valve along the pipeline segment connecting GWEX1 to the central control building.

- Replacement of the remotely controlled actuator on the main (delivery) pipeline valve at the north spray treatment site.

- $\quad$ Reinstallation of the government frequency radio modem at the south spray treatment site control panel, permitting remote monitoring and operation of the south spray treatment unit. The modem had previously been returned to the manufacturer (Pacific Crest) by Reinke Manufacturing, Inc., during the December 2005-November 2006 review period, to correct a fault - at no cost to Argonne or the CCC/USDA.

- Repair of the electrical control panel at the north spray treatment site by Reinke Manufacturing, Inc., to correct a failed internal transformer. 


\subsection{Well GWEX4 and the Air Stripping Unit}

Well GWEX4 and the shallow-tray air stripper required no maintenance or repairs during the review period.

\subsection{Operating and Maintenance Costs in December 2006-November 2007}

Operating and maintenance costs for this review period are summarized in Table 6.1, along with costs in previous review periods for comparison. The costs for the current review period include one-time expenses associated with the following:

- Replacement of the remotely controlled valve actuator at the north spray treatment site.

- Repair of the electrical control panel at the north spray treatment site.

The total operating and maintenance costs for the Utica project during the current review period $(\$ 134,056)$ decreased by approximately $50 \%$ relative to the equivalent costs for December 2005-November 2006 (\$270,916). This reduction reflects significantly lower costs in December 2006-November 2007 for the one-time expenses noted above $(\$ 7,336)$ and also for routine operation, support, monitoring, and oversight $(\$ 126,720)$, compared to the previous review period (\$62,731 and $\$ 208,186$, respectively). 
TABLE 6.1 Summary of operating and maintenance costs for the Utica restoration project.

\begin{tabular}{|c|c|c|c|}
\hline \multirow[b]{2}{*}{ Item } & \multicolumn{3}{|c|}{ Cost $(\$)$} \\
\hline & $\begin{array}{l}\text { Oct 2004- } \\
\text { Nov } 2005\end{array}$ & $\begin{array}{l}\text { Dec 2005- } \\
\text { Nov } 2006\end{array}$ & $\begin{array}{l}\text { Dec 2006- } \\
\text { Nov } 2007\end{array}$ \\
\hline \multicolumn{4}{|l|}{ Routine Costs } \\
\hline General Management & 18,127 & 17,699 & 5,544 \\
\hline Logistics Support & 64,145 & 74,713 & 10,475 \\
\hline Remediation Monitoring & 170,880 & 110,546 & 97,164 \\
\hline Technical Oversight & 17,727 & 5,228 & 13,537 \\
\hline SUBTOTAL & 270,879 & 208,186 & 126,720 \\
\hline \multicolumn{4}{|l|}{ Non-routine Costs } \\
\hline Monitoring Network Establishment & 11,707 & & \\
\hline Radio Control System & & 5,140 & \\
\hline Irrigation Span Repairs & & 57,591 & \\
\hline Valve Actuator Replacement & & & 5,071 \\
\hline Repair of North Spray Pad Control Panel & & & 2,265 \\
\hline SUBTOTAL & 11,707 & 62,731 & 7,336 \\
\hline TOTAL & 282,586 & 270,916 & 134,056 \\
\hline
\end{tabular}




\section{Summary}

System operations and costs in the three years of operation are summarized in Table 7.1.

A combined total of approximately 119 million gallons of contaminated groundwater was extracted and treated during the operation of the aquifer restoration systems at Utica from December 1, 2006, to November 30, 2007. Approximately $76 \%$ of the total volume treated (91 million gallons; 280 acre-feet) was used to supplement the natural water entering the North Lake Basin Wildlife Management Area.

Groundwater modeling studies performed by Argonne during the development of the aquifer restoration approach for Utica (Argonne 2000) indicated that, on average, the extraction of approximately 97 million gallons of groundwater per year would be required to achieve cleanup of the aquifer in approximately 10-15 years. The actual groundwater produced during the current review period represents approximately $123 \%$ of this average annual goal. The cumulative volume of groundwater extracted and treated by the Utica systems since the aquifer restoration efforts began at this site in November 2004 has met and exceeded the theoretical production target for this period, representing $103 \%$ of the combined annual goals for the three years.

Sampling and analysis of the effluent water from the air stripping and spray irrigation treatment units indicated that during the review period these systems functioned at a minimum efficiency of $95 \%$ (on the basis of data for individual samples). (Higher efficiency of approximately $98 \%$ was calculated on the basis of the average concentration delivered to the wetlands during the review period.) Carbon tetrachloride concentrations in all discharges of treated water at the site were below the permitted maximum target $(44.2 \mu \mathrm{g} / \mathrm{L})$ by roughly an order of magnitude.

Calculations based on the volumes and measured carbon tetrachloride concentrations of the groundwater extracted and treated during the review period indicated that approximately $25 \mathrm{~kg}$ (4.1 gal) of carbon tetrachloride was removed from the Utica aquifer during the current review period. The decrease in the quantity of carbon tetrachloride removed, in comparison to the previous period, primarily reflects a general decrease in the contaminant concentrations observed in untreated groundwater at extraction wells GWEX2-GWEX4, rather than a decrease in the volumetric throughput or contaminant removal efficiency of the groundwater treatment systems (Table 7.1). 
The costs incurred by Argonne for operating and maintenance of the aquifer restoration effort at Utica during the current review period were approximately $\$ 134,000$. Both non-routine repair expenses and routine operating costs for the Utica project were significantly lower than in the previous review period. These lower current costs were consistent with expectations for greater efficiency in operation with increased experience (Argonne 2005). 
TABLE 7.1 Summary of performance of the groundwater restoration systems at Utica.

Review Period

\begin{tabular}{|c|c|c|c|}
\hline \multirow[b]{2}{*}{ Performance Factor } & \\
\hline & $\begin{array}{l}\text { Oct 2004- } \\
\text { Nov } 2005\end{array}$ & $\begin{array}{l}\text { Dec 2005- } \\
\text { Nov } 2006\end{array}$ & $\begin{array}{l}\text { Dec } 2006- \\
\text { Nov } 2007\end{array}$ \\
\hline $\begin{array}{l}\text { Groundwater Produced (gal) } \\
\text { Groundwater Produced (\% of annual goal) } \\
\text { Groundwater Discharged to Wetlands (gal) }\end{array}$ & $\begin{array}{c}66,364,652 \\
68 \\
34,611,960\end{array}$ & $\begin{array}{c}113,949,510 \\
117 \\
84,365,500\end{array}$ & $\begin{array}{c}119,274,680 \\
123 \\
90,954,300\end{array}$ \\
\hline Carbon Tetrachloride in Combined Untreated Groundwater from GWEX1-GWEX3 ( $\mu \mathrm{g} / \mathrm{L})$ & $100-122$ & $71-139$ & $48-90$ \\
\hline Carbon Tetrachloride in Treated Spray Discharge ${ }^{a}$ (range of values, $\mu \mathrm{g} / \mathrm{L}$ ) & NDb-7.2 & ND-6.9 & ND-3.7 \\
\hline Carbon Tetrachloride in Treated Spray Discharge ${ }^{a}$ (average, $\mu \mathrm{g} / \mathrm{L}$ ) & 1.45 & 0.91 & 0.61 \\
\hline Carbon Tetrachloride in Untreated Groundwater at GWEX4 $(\mu \mathrm{g} / \mathrm{L})$ & $53-95$ & $26-70$ & $20-43$ \\
\hline Carbon Tetrachloride in Treated Air Stripper Effluent ${ }^{\mathrm{a}}(\mu \mathrm{g} / \mathrm{L})$ & ND & ND & ND \\
\hline Carbon Tetrachloride Removed (kg, gal) & $23,3.8$ & $34,5.6$ & $25,4.1$ \\
\hline \multicolumn{4}{|l|}{ Minimum Carbon Tetrachloride Removal Efficiency for Spray Treatment (\%) } \\
\hline Based on Individual Samples & $>94$ & $>93$ & $>95$ \\
\hline Based on Averages & $\sim 99$ & $\sim 99$ & $\sim 98$ \\
\hline Carbon Tetrachloride Removal Efficiency for Air Stripper (\%) & $>99$ & $>99$ & $>99$ \\
\hline pH of Treated Spray Discharge ${ }^{c}$ & $7.01-8.18$ & $7.10-8.32$ & $7.09-8.36$ \\
\hline $\mathrm{pH}$ of Treated Air Stripper Effluent $\mathrm{c}$ & $7.01-8.35$ & $7.50-8.58$ & 7.79-8.33 \\
\hline \multicolumn{4}{|l|}{ Costs $(\$)$} \\
\hline Routine & 270,879 & 208,186 & 126,720 \\
\hline Non-routine & 11,707 & 62,731 & 7,336 \\
\hline TOTAL & 282,586 & 270,916 & 134,056 \\
\hline
\end{tabular}

a Compliance level, $44.2 \mu \mathrm{g} / \mathrm{L}$.

b ND, not detected at a method detection limit of $0.1 \mu \mathrm{g} / \mathrm{L}$.

c Compliance level, 6.5-9.0. 


\section{References}

Argonne, 2000, Final Report: Stage I Investigations of the Agricultural/Environmental Enhancement Pilot Program, Utica, Nebraska, prepared for the Commodity Credit Corporation, U.S. Department of Agriculture, Washington, D.C., by Argonne National Laboratory, Argonne, Illinois, January.

Argonne, 2004, Final Monitoring Plan for the Utica Aquifer-North Lake Basin Restoration Project at Utica, Nebraska, ANL/ER/TR-04/006, prepared for the Commodity Credit Corporation, U.S. Department of Agriculture, Washington, D.C., by Argonne National Laboratory, Argonne, Illinois, November.

Argonne, 2005, Summary of First-Year Operations and Performance of the Utica Aquifer and North Lake Basin Wetlands Restoration Project in October 2004-November 2005, ANL/EVS/AGEM/TR-05-06, prepared for the Commodity Credit Corporation, U.S. Department of Agriculture, Washington, D.C., by Argonne National Laboratory, Argonne, Illinois, December.

Argonne, 2006, Summary of Operations and Performance of the Utica Aquifer and North Lake Basin Wetlands Restoration Project in December 2005-November 2006, ANL/EVS/AGEM/TR06-11, prepared for the Commodity Credit Corporation, U.S. Department of Agriculture, Washington, D.C., by Argonne National Laboratory, Argonne, Illinois, December. 
Argonne

Environmental Science Division

Argonne National Laboratory

9700 South Cass Avenue, Bldg. 203

Argonne, IL 60439-4843

www.anl.gov

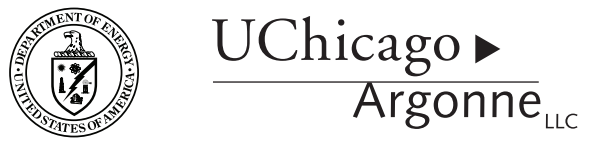

A U.S. Department of Energy laboratory

managed by UChicago Argonne, LLC 